\title{
PELATIHAN PEMANFAATAN SAMPAH DAPUR MENJADI ANEKA MENU MAKANAN YANG LAYAK KONSUMSI, LEZAT, DAN SEHAT BAGI ANGGOTA PKK RW 02 KELURAHAN DINOYO KECAMATAN LOWOKWARU KOTA MALANG
}

\author{
Nanik Wahyuni ${ }^{1}$, Ulfi Kartika ${ }^{2}$, Eko Suprayitno ${ }^{3}$ \\ 1,2,3 Universitas Islam Negeri Maulana Malik Ibrahim Malang \\ Email: nanik@akuntansi.uin-malang.ac.id
}

\begin{abstract}
Kitchen waste is rubbish that is produced from leftover food that cannot be processed, such as vegetables, skin of onions that unwittingly every day will be wasted and accumulate so much kitchen waste. If there are around 1500 households in Dinoyo, then the amount of garbage collected per day ranges from $4,500 \mathrm{~kg}$ to $7,500 \mathrm{~kg}$. In order to reduce a lot of kitchen waste, the service aims to provide training on the use of kitchen waste into a variety of food menus that are suitable for consumption, delicious, and healthy for PKK RW 02 Dinoyo Urban District Lowokwaru District Malang City. The steps in implementing the training are the data collection stage and the training implementation stage. The target of the training participants are PKK RW 02 Dinoyo Subdistrict, Lowokwaru District, Malang City by providing direct practice in making various foods made from kitchen waste such as onion chips. The results of the training activities can increase the knowledge and skills of PKK mothers so that they can be practiced independently at home because the manufacturing process is quite easy and future prospects can help improve the community's economy.
\end{abstract}

Keywords: Kitchen Waste, Food Waste

\section{PENDAHULUAN}

\section{Analisis Situasi}

Memasak merupakan rutinitas yang dilakukan oleh setiap rumah tangga pada setiap hari. Berbagai bahan makanan diolah menjadi sebuah masakan yang lezat dan nikmat untuk disajikan. Memasak merupakan sebuah ilmu otodidak yang dimiliki oleh setiap orang.. Dalam proses memasak tentunya tidak semua bagian dari bahan makanan yang digunakan dapat diolah menjadi masakan, sebagian dari bahan tersebut pasti akan dibuang karena dianggap sebagai sampah. Seperti halnya sayur, seikat sayur hanya akan digunakan daunnya yang masih hijau dan segar untuk dijadikan masakan dan sisanya akan dibuang (Sujiyanto, 2016). Tanpa disadari, setiap hari akan membuang sampah dapur begitu banyak yang berasal dar isisa bahan makanan yang tidak dapat diolah. Hampir semua orang menganggap bahwa sisa bahan makanan yang tidak dapat diolah hanyalah sebuah sampah yang seharusnya dibuang. Tetapi, pada kenyataannya justru sisa bahan makanan inilah yang mengandung zat gizi atau masih memiliki kandungan gizi. Untuk mengurangi jumlah sampah dalam rumah tangga, setiap orang seharusnya dapat mengolah sampah menjadi sesuatu yang bernilai tinggi. Salah satunya adalah sampah sisa bahan makanan (Rizal, 2011). Banyak ide yang dapat diterapkan untuk mengolah sampah dapur tersebut menjadi sesuatu yang lebih bernilai guna. Salah satunya adalah menjadikannya makanan yang lezat, nikmat, serta bergizi tinggi. Banyak ide kreatif yang dapat dijadikan sebagai inspirasi untuk mengolah sampah tersebut menjadi sebuah makanan dan minuman yang memiliki nilai 
tinggi (Sunyoto,2008). Bukan hanya untuk konsumsi pribadi tetapi juga dapat dijual kembali.

Setiap keluarga selalu mempunyai sampah, terutama sampah dapur. Setiap hari ratarata satu keluarga menghasilkan sampah dapur antara $3 \mathrm{Kg}$ sampai $5 \mathrm{Kg}$. Jika di Kelurahan Dinoyo terdapat sekitar $1500 \mathrm{KK}$, maka kira-kira jumlah sampah yang dikumpulkan per hari berkisar antara 4.500 Kg sampai $7.500 \mathrm{Kg}$ (Arief, 2013). Belum lagi Kelurahan Dinoyo merupakan daerah yang terletak disekitar kampus, sehingga banyak masyarakat yang menerima mahasiswa untuk kost di rumahnya. Maka secara otomatis jumlah sampah semakin banyak.

Adapun tujuan yang ingin dicapai dari pengabdian ini adalah:

a. Peningkatan pemanfaatan limbah sampah dapur rumah tangga untuk mengurangi limbah sampah rumah tangga.

b. Pemanfaatan limbah sampah dapur diharapkan dapat meningkatkan gizi dan kualitas hidup masyarakat.

c. Pemanfaatan limbah sampah dapur diharapkan dapat meningkatkan ekonomi rumahtangga melalui penghematan pengeluaran biaya konsumsi masing-masing rumah.

\section{Permasalahan}

Tim UIN Mengabdi berkoordinasi dengan ketua PKK RW 02 dan beberapa ketua PKK RT yang berada di lingkungan RW 02 Kelurahan Dinoyo Kota Malang mengidentifikasi berbagai kemungkinan pemanfaatan limbah atau sampah dapur untuk diolah kembali menjadi makanan.

\section{Kondisi saat ini}

Kelurahan Dinoyo merupakan salah satu kelurahan yang teermasuk dalam wilayah kota Malang. Lokasinya yang strategis terletak diantara beberapa perguruan tinggi negeri dan swasta, antara lain Universitas Brawijaya, Universitas Islam Negeri (UIN) Maulana Malik Ibrahim Malang, Universitas Muhammadiyah Malang, Universitas Islam Malang, Universitas Gajayana dan lainnya. Melihat lokasinya, tentu saja kelurahan Dinoyo ini mempunyai merupakan daerah pemukiman yang padat. Hal ini disebabkan karena rata-rata setiap rumah atau keluarga menerima kost bagi mahasiswa yang sedang kuliah di universitas sekitarnya.

Daerah pemukiman yang padat tentu saja menghasilkan sampah yang tidak sedikit. Menurut $\mathrm{P}$ Man, salah satu petugas kebersihan atau pengangkut sampah di lingkungan kelurahan Dinoyo, bahwa setiap petugas pengengkut sampah rata-rata dalam sehari mereka 5 sampai 6 kali bolak balik mengangkut sampah ke tempat pembuangan sampah dengan menggunakan gerobak.

Data rata-rata volume sampah dapur yang dihasilkan per rumah tangga per hari dapat dilihat pada Tabel 1 di bawah ini. 
PEDULI: Jurnal Ilmiah Pengabdian Pada Masyarakat, 2020, Vol.4, No.1 ISSN: 25974653. EISSN:25974688 http://peduli.wisnuwardhana.ac.id/index.php/peduli/index

Tabel 1.

Rata-rata volume sampah dapur yang dihasilkan per rumah tangga per hari di lokasi kegiatan pengabdian

\begin{tabular}{|l|l|l|l|}
\hline Sampah \\
Organik (lt) & \multicolumn{3}{|l|}{ Sampah Anorganik } \\
\cline { 2 - 4 } & Sampah Plastik (gr) & Sampah Kertas (gr) & $\begin{array}{l}\text { Sampah } \\
\text { Kaleng (gr) }\end{array}$ \\
\hline 2,67 & 10,81 & 4,03 & 1,83 \\
\hline
\end{tabular}

Sumber. Data diolah

\section{Kajian Teori}

Sampah merupakan material sisa yang tidak diinginkan setelah berakhirnya suatu proses. Sampah didefinisikan oleh manusia menurut derajat keterpakaiannya, dalam proses-proses alam sebenarnya tidak ada konsep sampah, yang ada hanya produk-produk yang dihasilkan setelah dan selama proses alam tersebut berlangsung. Salah satu sifat sampah dibedakan menjadi :

a. Garbage, yakni jenis sampah yang terdiri dari sisa-sisa potongan hewan atau sayuran hasil pengolahan dari dapur rumah tangga, hotel, restoran, semuanya mudah membusuk.

b. Rubbish, yakni pengolahan yang tidak mudah membusuk. Pertama yang mudah terbakar, seperti kertas, kayu dan sobekan kain. Kedua yang tidak mudah terbakar, misalnya kaleng, kaca dan lain-lain.

c. Ashes, yakni semua jenis abu dari hasil pembakaran baik dari rumah maupun industri.

d. Street sweeping, yakni sampah dari hasil pembersihan jalanan, seperti halnya kertas, kotoran, daun-daunan dan lain-lain.

e. Dead animal, yakni bangkai binatang yang mati karena alam, kecelakaan maupun penyakit.

f. Abandoned vehicle, yakni bangkai kendaraan, seperti sepeda, motor, becak, dan lain-lain.

g. Sampah khusus, yakni sampah yang memerlukan penanganan khusus, misalnya kalengkaleng cat, zat radioaktif, sampah pembasmi serangga, obat-obatan dan lain-lain (Anonim,1986).

Dampak sampah terhadap sosial dan ekonomi

a. Pengelolaan sampah yang kurang baik akan membentuk lingkungan yang kurang menyenangkan bagi masyarakat: bau yang tidak sedap dan pemandangan yang buruk karena sampah bertebaran dimana-mana.

b. Memberikan dampak negatif terhadap kepariwisataan.

c. Pengelolaan sampah yang tidak memadai menyebabkan rendahnya tingkat kesehatan masyarakat. Hal penting di sini adalah meningkatnya pembiayaan secara langsung (untuk mengobati orang sakit) dan pembiayaan secara tidak langsung (tidak masuk kerja, rendahnya produktivitas).

d. Pembuangan sampah padat ke badan air dapat menyebabkan banjir dan akan memberikan dampak bagi fasilitas pelayanan umum seperti jalan, jembatan, drainase, dan lain-lain. 
e. Infrastruktur lain dapat juga dipengaruhi oleh pengelolaan sampah yang tidak memadai, seperti tingginya biaya yang diperlukan untuk pengolahan air. Jika sarana penampungan sampah kurang atau tidak efisien, orang akan cenderung membuang sampahnya di jalan. Hal ini mengakibatkan jalan perlu lebih sering dibersihkan dan diperbaiki.

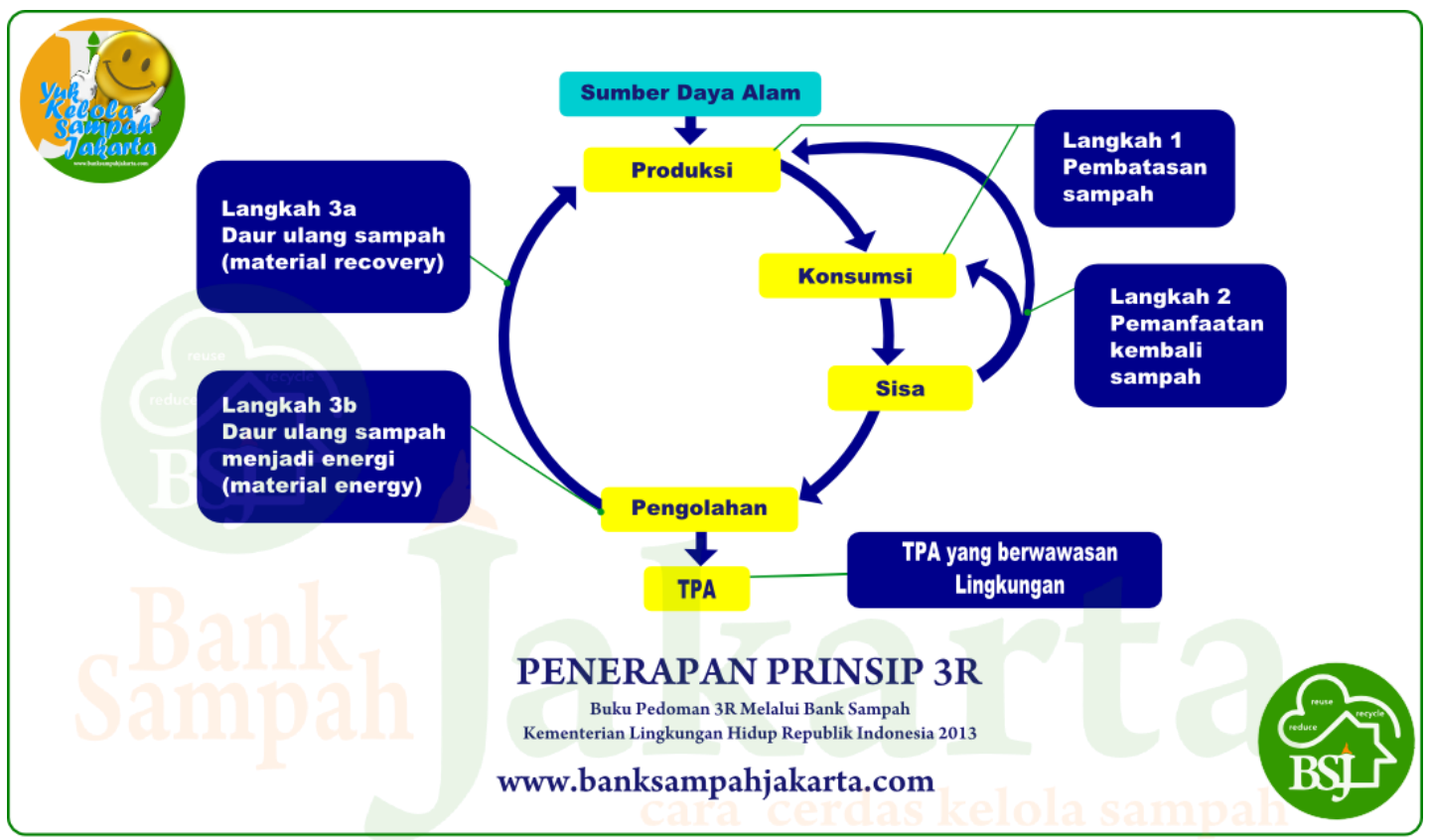

Sumber: Bank sampah Jakarta, diakses September 2019.

\section{Pengelolaan sampah dengan prinsip 3R}

Pengelolaan sampah dengan prisip 3R terkait langsung dengan prinsip pembangunan berkelanjutan (sustainable development), yaitu dalam pelaksanaan penghematan sumber daya (resource efficiency) dan penghematan energi (energy efficiency).

Dengan menjalankan prinsip Reuse Recycle Reduse akan terlaksana upaya pengurangan ekploitasi sumber daya karena sebagian bahan baku dapat terpenuhi dari pemanfaatan sampah yang didaur-ulang dan sampah yang diguna-ulang. Penggunaan bahan baku daur ulang untuk menghasilkan suatu produk terbukti menggunakan lebih sedikit energi dibandingkan jika menggunaka bahan baku alami (virgin material).

Dengan inovasi dari berbagai pihak, saat ini sampah adalah sumber energi alternatif pengganti energi fosil. Pemanfaatan sampah sebagai baan baku pebangkit energi sudah merupaka hal yang lazim di beberapa negara maju dengan menerapakan metode, Insenerasi, methane capture, biomass atau refuse derived fuel (RDF).

Penerapan prinsip 3R reuse recycle reduse dalam pengelolaan sampah adalah langkah cerdas untuk mengatasi semakin terbatasnya sumber daya alam dan kelangkaan energy (Bank Sampah Jakarta, 2019) 


\section{METODE PELAKSANAAN}

Dalam upaya meningkatkan pemanfaatan sampah dapur model pelatihan yang diberikan kepada ibu-ibu PKK. melalui beberapa tahapan program yaitu program pengenalan jenis dan macam-macam sampah dapur dan tahap program pelatihan pemanfaatan sampah dapur selanjutnya program peningkatan ekonomi keluarga melalui pemanfaatn sampah dapur.

Partisipatory action research berguna sebagai jembatan untuk meningkatkan kesadaran masyarakat dampingan dalam memahami, menginginkan, dan memecahkan permasalahan sampah dapur (Mikelsen, 2001). Program ini sebagai fasilitator bagi masyarakat untuk pemecahan masalah sampah dapur. Namun perumusan jalan keluar dan strategi ini tetap melibatkan masyarakat dengan harapan apabila masyarakat mengalami masalah lain, mereka bisa memecahkan permasalahan mereka sendiri tanpa bantuan orang lain.

Berikut strategi yang dipergunakan dalam pengabdian :

\section{Tahap I}

a. Pengumpulan data dari ibu-ibu PKK mengenai jenis dan macam bahan limbah sampah dapur masing-masing rumah tangga.

b. Identifikasi komposisi sampah dapur rumah tangga di lingkungan PKK RW 02 Kecamatan Lowokwaru Kota Malang.

II. Tahap II

a. Pelatihan pengolahan makanan berbahan baku sampah dapur.

a. Pematangan alternatif lain dalam pengolahan makanan yang mempunyai nilai jual.

\section{HASIL KARYA UTAMA DAN PEMBAHASAN}

Sampah dapat menimbulkan bahaya atau gangguan terhadap lingkungan jika tidak dikelola dengan baik (Sadono \& Antonius, 1996; Sutisna, 1995 Dalam Al Muhdhar, 2001). Pengolahan sampah merupakan salah satu upaya membuat sampah memiliki manfaat dan memiliki nilai ekonomis sekaligus dapat mengurangi volume sampah yang semakin menumpuk tiap harinya (Zubair, 2012). Oleh sebab itu perlu adanya pengolahan sampah yang bisa mengurangi volume sampah dan juga bisa memberikan nilai tambah, aktivitas pengolahan sampah itu yang dinamakan pola daur ulang (Oswari, 2006). Materi atau zat yang dihasilkan dari aktifitas manusia dalam rumah tangga, komersil dan industri baik bersifat organik maupun anorganik dinamakan sampah (Cointrean dalam Satori, 2010).

Sisa makanan rumah merupakan kelompok sampah organik meskipun porsinya cukup tinggi, namun kategori ini merupakan sampah yang dapat membusuk dan terurai. Sehingga, sampah organik seharusnya tidak menimbulkan masalah lingkungan, selama dikelola dengan baik. Sampah dapur termasuk didalamnya sisa makanan, sayuran, hingga tumbuhan merupakan sampah yang diproduksi paling banyak dengan komposisi $60 \%$ dari seluruh sampah. Langkah awal dalam pengelolaan sampah dapat dimulai dari tingkat rumah tangga. Saat ini, mayoritas masyarakat Indonesia masih belum melakukan tindakan pengolahan sampah di masing-masing rumahnya. Maka dalam kegiatan UIN Mengabdi ini peneliti memfokuskan pada pelatihan untuk mengolah makanan atau camilan dengan bahan dasar barang yang mudah didapat seperti sampah dapur dan bahan yang harganya relatif murah. 
Output dari pelatihan ini adalah hasil olahan bahan-bahan ini akan mempunyai nilai jual dibandingkan sebelumnya.

Berdasar hasil observasi ditemukan ibu-ibu PKK RW 02 Kelurahan Dinoyo Kecamatan Lowokwaru Kota Malang mengaku masih kurang teredukasi dalam hal pengolahan sampah dapur. Masyarakat yang diwakili ibu-ibu menyatakan keinginan untuk menambah pengetahuan tentang pengolahan sampah dapur karena mereka ingin memanfaatkan sampah dapur tersebut. Data juga menunjukkan bahwa masyarakat belum tersadarkan bahaya volume sampah yang terus menumpuk, Mereka juga belum tersadarkan dampak kebiasaan tidak memilah sampah organik dan unorganik di masing-masing rumah. Kondisi lingkungan yang cukup padat sehingga lokasi tempat sampah sangat berdekatan dengan ruang aktivitas keluarga sehari-hari.

UIN Mengabdi mencoba berbagi pengetahuan tentang pemanfaatan sampah dapur mengingat ibu-ibu PKK RW 02 Kelurahan Dinoyo banyak yang berprofesi sebagai ibu rumah tangga dan volume sampah dapurnya juga cukup banyak. Pengolahan sampah dapur di tetapkan sebagai tema pelatihan yang diberikan dengan mempraktekkan langsung pada saat pelatihan. Adapun tahapan pelaksanaan pelatihan meliput:

\section{a. Tahap persiapan,}

Pada tahap ini dilakukan survey tempat dilaksanakannya pelatihan, jumlah peserta dan membagi peserta menjadi beberapa kelompok kerja ketika pelatihan, penyusunan bahan dan alat pelatihan, merancang alat evaluasi produk terkait tanggapan peserta (tingkat kesukaan), menyiapkan materi praktik pembuatan aneka keripik berbahan kulit bawang, singkong dan pisang dalam bentuk resep yang dengan jelas menjabarkan bahan, alat, dan cara membuatnya.

\section{b. Tahap pelaksanaan,}

Pada tahap ini, dilaksanakan kegiatan pelatihan pada hari Minggu, tanggal 8 September 2019 dan tanggal 29 September di Jl. Gajayana gg V termasuk dalam wilayah RW.02 Kelurahan Dinoyo, Kota Malang. Pelaksaan Praktek Pengolahan sampah dapur keripik Kulit Bawang dan acar kulit semangka dan pengolahan dan pengemasan Kripik Singkong aneka rasa dan keripik pisang serta pisang sale di wilayah Jl. Gajayana bagi IbuIbu PKK RW. 02 Kelurahan Dinoyo Kota malang ini adalah sebagai berikut.

1) Memberikan pengetahuan dan keterampilan dalam bentuk pelatihan dalam pengolahan sampah dapur keripik kulit bawang dan kulit semangka, Pembuatan dan Pengemasan Kripik Singkong aneka rasa dan keripik pisang serta pembuatan sale pisang dengan bentuk yang lebih menarik.

2) Memberikan pelatihan penerapan teknik atau metode yang dapat digunakan dalam membuat cemilan keripik kulit bawang dan kulit semangka, Pembuatan dan Pengemasan Kripik bawang merah, kulit semangka dan singkong aneka rasa, agar mudah dipahami serta memiliki kualitas baik dari segi rasa, dan tekstur, sehingga dapat layak dikonsumsi dan disukai oleh konsumen (masyarakat umum). 
PEDULI: Jurnal Ilmiah Pengabdian Pada Masyarakat, 2020, Vol.4, No.1 ISSN: 25974653. EISSN:25974688 http://peduli.wisnuwardhana.ac.id/index.php/peduli/index
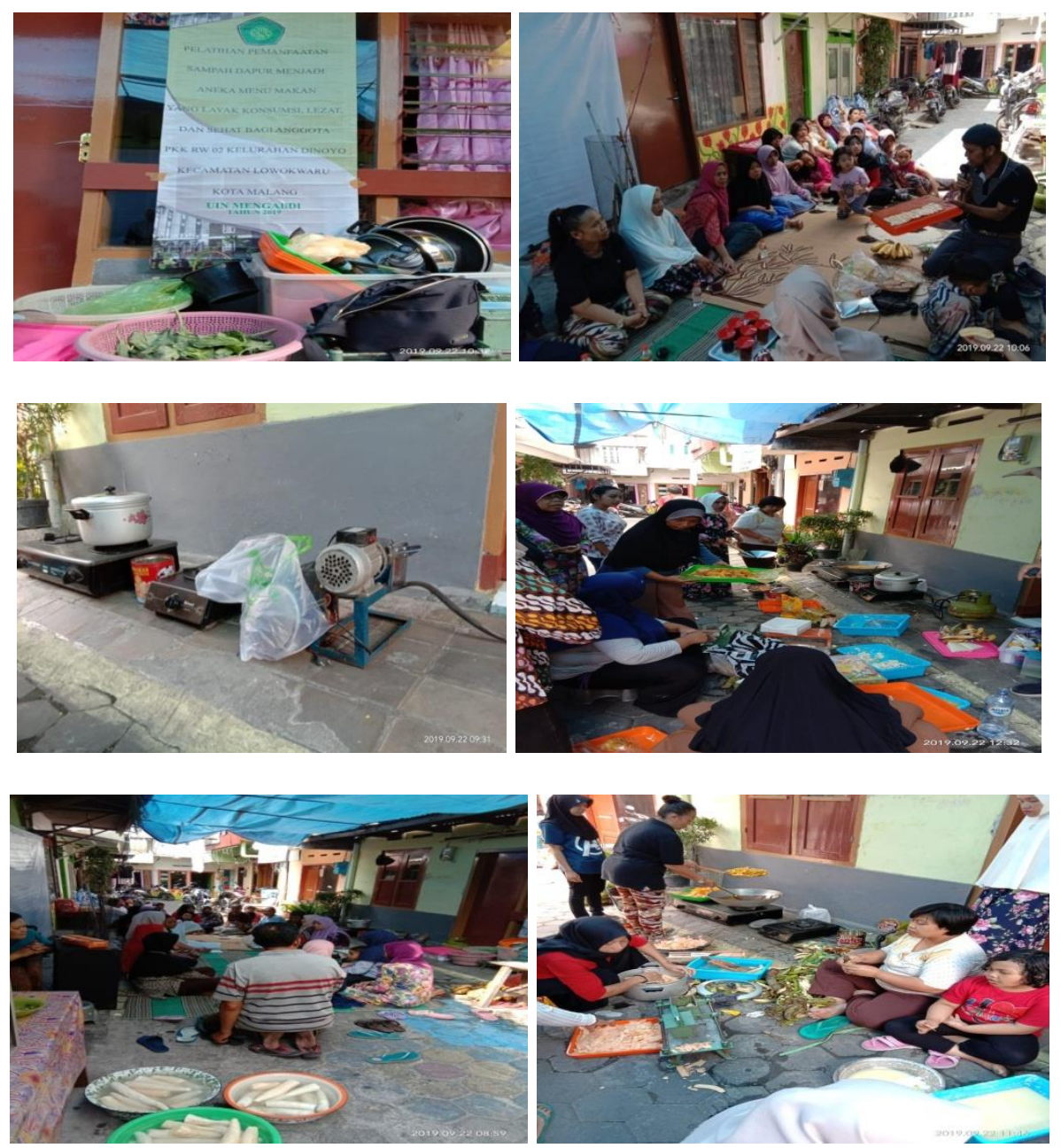

Ganbar 1. Pelaksanaan Pelatihan Pembuatan makanan berbahan sampah dapur

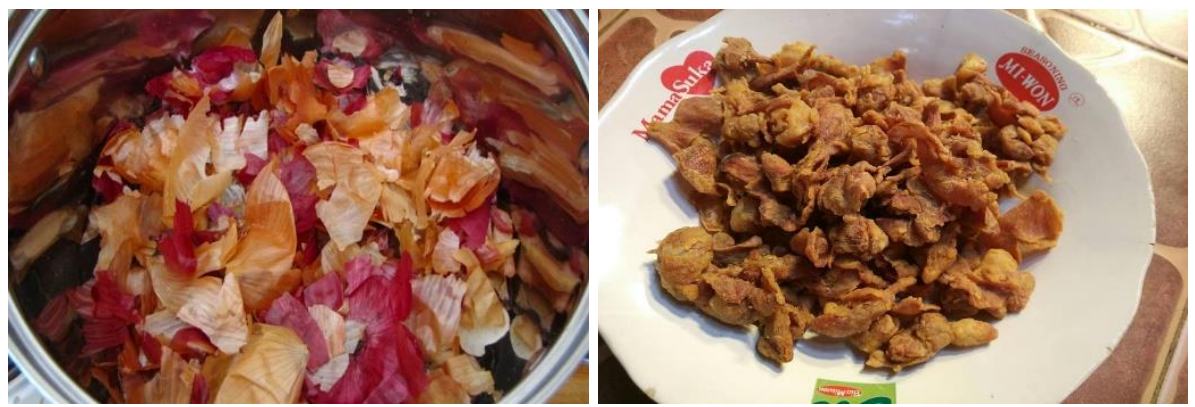

Gambar 2. Hasil Produk Keripik Kulit Bawang Merah 

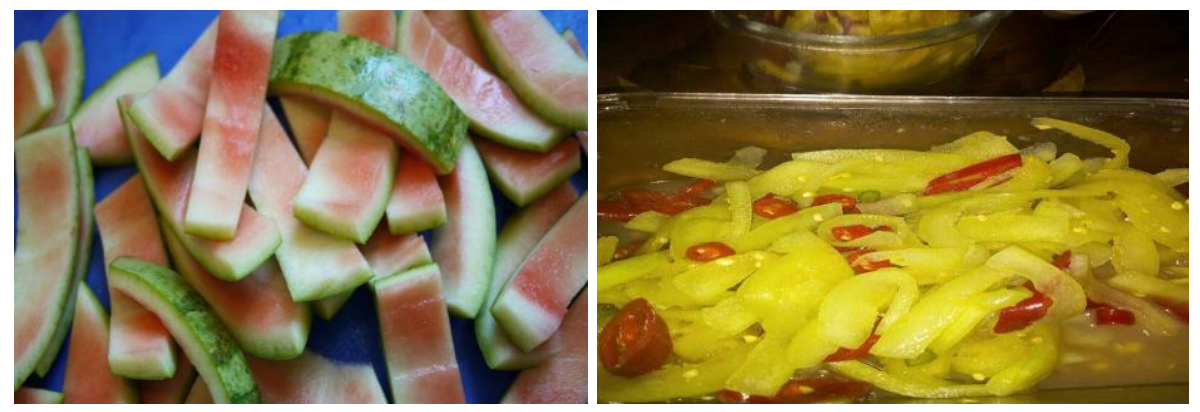

Gambar 3. Hasil Produk Manisan Semangka

Hasil yang didapatkan dari pelatihan ini adalah meningkatnya pengetahuan ibu-ibu PKK RW 02 Kelurahan Dinoyo Kecamatan Lowokwaru Kota Malang mengenai pengolahan bahan makanan dari sampah dapur, selain itu ibu-ibu juga tergali bakatnya dalam menginovasi makanan dengan bahan dasar sampah dapur yang lain.Wawasan dan motivasi ibu-ibu PKK RW 02 Kelurahan Dinoyo Kecamatan Lowokwaru Kota Malang juga tercerahkan dengan berbagai sharing pengalaman dan ilmu dari narasumber yang merupakan seorang praktisi entrepreneur. Dampak jangka panjang diharapkan dari pelatihan ini semakin menambah efektifitas dan efisiensi penggunaan bahan masakan di dapur juga meningkatkan motivasi berwirausaha.

\section{Kesimpulan}

Kegiatan pelatihan ini merupakan salah satu cara untuk menciptakan peluang usaha baru dan untuk meningkatkan kesejahteraan guna memenuhi semua kebutuhan hidup. Kegiatan ini juga diharapkan dapat membantu pemerintah dalam mengurangi angka pengangguran dan persoalan sosial di masyarakat, melalui program pelatihan kepemudaan. Melalui kagiatan pelatihan pembuatan keripik yang di lakukan bersama dengan ibu-ibu PKK RW 02 binaan yang ada di Desa Kecamatan Lowokwaru Kota Malang diharapkan bisa dijadikan suatu contoh dalam program pemberdayaan masyarakat. Hasil dari kegiatan pembinaan tersebut dapat menambah pengetahuan dan keterampilan para pemuda binaan. .Kegiatan pembinaan pembuatan keripik ini dapat dipraktekan oleh pemuda binaan dan masyarakat secara langsung karena proses pembuatan keripik ini cukup mudah dan prospek kedepannya pun dapat membantu meningkatkan perekonomian masyarakat. Pengembangan produk pada pembuatan keripik kulit bawang, keripik singkong aneka rasa dan keripik pisang penting dilakukan untuk meningkatkan penampilan dan kualitas agar bisa diterima oleh masyarakat luas. Selain itu juga, peningkatan pengetahuan tentang bahan-bahan tambahan makanan yang aman dikonsumsi bagi masyarakat dan juga pemahaman dan tambahan pengetahuan tentang bahan pengawet yang aman.

Namun dalam kegiatan pembinaan pembuatan keripik ini pun mengalami beberapa kendala yang harus dihadapi oleh para ibu-ibu RT antara lain keripik hanya dipasarkan karena masih terbatasnya keripik yang dihasilkan, penggunaan label, belum ada upaya mempromosikan keripik ke daerah lain, belum adanya upaya pengemasan yang lebih menarik minat pembeli dan belum dilakukan kerja sama dengan pihak - pihak terkait yang dapat membantu upaya pemasaran keripik. 


\section{DAFTAR PUSTAKA}

Al Muhdhar, Mimien H. I. 2001. Pengelolaan Sampah Rumah Tangga. Malang :

Departemen Pendidikan Universitas Negeri Malang.

Arief, sofyan. 2013. Pengelolaan Sampah Malang Raya Menuju Pengelolaan Sampah Terpadu Yang Berbasis Partisipasi Masyarakat, volume 2 nomor 8. Jurnal Humanity, ISSN 0216-8995

Mikelsen, Britha, 2001. Metode Penelitian Partisipatory dan Upaya-upaya Pemberdayaan: Sebuah Buku Pegangan bagi Praktisi lapangan. Jakarta. Yayasan Obor Indoensia.

Oswari. 2006. Potensi Nilai Ekonomis Pengelolaan Sampah Di Kota Depok. (Online)http://publication.gunadarma.ac.id/bitstream/123456789/596/1/UnlockTeddy_doddy_59-69.pdf Diakses Pada 30 Agustus 2019

Rizal M. (2011). Analisis Pengelolaan Persampahan Perkotaan (Studi kasus pada kelurahan Boya Kecamatan Banawa Kabupaten Donggala). Jurnal Sipil Mesin Arsitektur Elektro (SMARTek) volume 9 nomor 2: 155-172.

Robert G. Bringle, Julie A. Hatcher, and Rachel E. McIntosh. 2006, "Analyzing Morton"s Typology of Service Paradigms and Integrity," dalam Michigan Journal of Community Service Learning, MJCSL 13-1 10/11/06 (Fall 2006): 5-15.

Satori, Mohamad Dkk. 2010. Pendampingan Usaha Masyarakat Dalam Memanfaatkan Sampah Di Desa Manis Lor Kabupaten Kuningan. (Online) http://prosiding.lppm.unisba.ac.id/index.php/Sains/article/view/133/pdf\#.VALl1XK Sz_A Diakses Pada 30 Agustus 2014 Volume 1 No.1 2010.

Suyoto, Bagong. 2008. Rumah Tangga Peduli Lingkungan. Prima Media, Jakarta.

Sujiyanto.2016. Analisis Pengolahan Sampah di Bank Sampah Malang. Vol. 5 No.3 Jurnal Ilmu Sosial dan Ilmu Politik.

Zubair, Achmad \& Haeruddin. 2012. Studi Potensi Daur Ulang Sampah Di Tpa Tamangapa Kota Makassar. (Online) http://download.portalgaruda.org/article.php?article=94529\&val=2170\&title= Diakses Pada 30 Agustus 2019 